\title{
DIZZINESS - PATHOGENESIS, DIAGNOSIS AND TREATMENT
}

\section{Marek Tomaszewski ${ }^{1}$, Katarzyna Banakiewicz², Krzysztof Jajko² ${ }^{2}$ Roman Szypowski², Paweł Zieliński ${ }^{2}$, Grzegorz Zalewski², Grażyna Olchowik ${ }^{1}$}

\author{
${ }^{1}$ Pope John Paul II State School of Higher Education in Biała Podlaska \\ ${ }^{2}$ Anatomic Group at the Chair and Department of Human Anatomy, Medical University of Lublin
}

Tomaszewski M., Banakiewicz K., Jajko K., Szypowski R., Zieliński P., Zalewski G., Olchowik G. (2015), Dizziness - pathogenesis, diagnosis and treatment. Health Problems of Civilization, 1 (9), p. 11-17

Summary: Dizziness is a symptom of many diseases. Patients very frequently come with such ailment to the hospital emergency department. It is a state which may last a few seconds or minutes and increase or recede with time. Therefore, the admitted patients frequently cannot assess their own illness in a precise and objective way. The dizziness definition is also quite ambiguous. Dizziness is defined as the sensation of one own's body movement or spinning and movement of the surrounding. It is very important to record the patient's medical history since the diagnostic procedure may depend on the symptoms' character. Dizziness may be a symptom of a serious disease, although it is not easy to find its cause. It appears not only in case of the labyrinth and nervous system disorders, but also in the systemic and functional diseases.

Dizziness and balance disorder are the direct cause of admitting one in every thirty patients. The symptom indicated the directly life-threatening disease only within the $3-8.5 \%$ of patients (cerebral circulation insufficiency - 6\%, cardiac dysrhythmia - 1.5\%, brain tumour $<1 \%$ ). Analyzing the data concerning the problem of dizziness occurrence within the general population, it has been noticed that this symptom has been reported two or three times more frequent by women than by men.

Dizzinesses are classified pathogenetically and clinically into labyrinthine and non-labyrinthine, paroxysmal and permanent, acute and chronic.

Dizziness is hard to diagnose because the symptoms reported by patients are only their own subjective sensations. The data presented in the article implicate the increasing number of patients with such disorders. Apart from dizziness, the patients complain also about the hearing disorders and nausea, which make their proper functioning impossible.

It is inappropriate to start the treatment without knowing the cause. Establishing, on the basis of patient's medical history and physical examination, whether the dizziness is of peripheral or central origin, is essential for the further diagnosis. After establishing the main diagnosis, the casual and symptomatic treatment is implemented, in some cases - there is a vestibular rehabilitation or even a surgical treatment.

Keywords: dizziness, labyrinth, internal ear

\section{Introduction}

Dizziness is a symptom of many diseases. Patients come with such ailment to the hospital emergency department very frequently. It is a state which may last a few seconds or minutes and increase or recede with time. Therefore, the admitted patients frequently cannot assess their own illness in a precise and objective way. The dizziness definition is also quite ambiguous. Dizziness is defined as the sensation of one own's body movement or spinning and movement of the surrounding.

It is very important to record the patient's medical history since the diagnostic procedure may depend on the symptoms' character. Dizziness may be a symptom of a serious disease, although it is not easy to find its cause. They appear not only in case of the labyrinth and nervous system disorders, but also in the systemic and functional diseases.

Primarily, the neurology and laryngology experts are the ones who deal with the dizziness treatment, although, in many cases, it is an inderdisciplinary problem due to its complicated aetiology. The dizziness treatment is based on casual and symptomatic treatment. Pharmacology, vestibular rehabilitation, and surgical treatment are applied.

\footnotetext{
Address for correspondence: Marek Tomaszewski, Pope John Paul II State School of Higher Education in Biała Podlaska, Sidorska 95/97 Street, 21-500 Biała Podlaska, e-mail: tomaszewski.marek@gmail.com, phone: (83) 3449918

Tables: 1 Figures: 0 References: 33 Full-text PDF www.hpc.edu.pl Copyright (c) Pope John Paul II State School of Higher Education in Biała Podlaska, Sidorska 95/97, 21-500 Biała Podlaska Indexation: Index Copernicus, Database AGRO, ProQuest, Polish Ministry of Science and Higher Education. This is an open-access article distributed under the terms of the Creative Common Attribution Non-commercial license (http://creativecommons.org/licenses/by-nc/3.0), which permits use, distribution and reproduction in any medium, provided the original works is properly cited, the use is non-commercial and is otherwise in compliance with the license.
} 


\section{Epidemiology}

Dizziness and balance disorder are the direct cause of admitting one in every thirty patients. The symptom indicated the directly life-threatening disease only within the 3-8.5\% of patients (cerebral circulation insufficiency - 6\%, cardiac dysrhythmia - 1.5\%, brain tumour < 1\%) (Seemungal 2007; Kroenke et al. 2000).

According to the data collected and analyzed by the researchers of Medical University of Baltimore in the United States, the diagnosis of the patients experiencing dizziness in the emergency department becomes more and more expensive. The research conducted in 2003-2008 indicates that 4 billion dollars were spent averagely per year, which represent $4 \%$ of all the costs borne by those departments in the United States. It has been observed that increasing number of patients reporting dizziness has been admitted to hospital. At the same time, the frequency of doing the imaging tests has also increased (Saber Tehrani et al. 2013).

Analyzing the data concerning the problem of dizziness occurrence within the general population, it has been noticed that this symptom was reported two or three times more frequent by women than by men (Neuhauser, Lempert 2009). According to the British research covering the large population of people (2000) of working age (18-64 years old), dizziness is a problem concerning many adults. About $20 \%$ of people felt dizziness at least once in a month. Out of this group, nearly $1 / 3$ of people suffered from the recurring dizziness for few years (Tacikowska, Kubiczek-Jagielska 2010).

Elderly people report the problems with balance and anxiety about falling down more frequently than any other age group (Colledge 1999). They occurr in case of one out of five people over 65 years old. The serious cause of dizziness is found among $20 \%$ of patients over 50 years old (Lo 2013).

The disease concerns also the children. The research on the group of 1050 children conducted by Riina Niemensivu and et al. implied that $23 \%$ of the children suffered from dizziness, which considerably influences their comfort of life, $8 \%$ of them experienced dizziness at least once (Niemensivu et al. 2006).

\section{Dizziness classification}

Dizziness classification into systemic and non-systemic, introduced by Hitz in the 19the century, is still applied in the clinical practice.

When the ailments are sudden and paroxysmal, the patients report the sensation of spinning and moving of the surrounding against their own bodies; it suggests the systemic, also known as peripheral, aetiology of dizziness (Domżał 2010). The above mentioned symptoms do not usually last longer than 3 weeks; they are often accompanied by hearing impairment, and head movements intensify the ailments (Storper 2005). This state is mostly caused by damaging the peripheral part of vestibular system. The patient is then able to point the direction of spinning and such type of dizziness is called "vertigo".

The less specific sensation of posture and walk instability, hardly determinable time of first symptoms, and chronic complaints indicate the dizziness of non-systemic, or central origin. Visual impairments, convulsion, and loss of consciousness are also typical for the described problem. Such ailments is usually of neurological origin (Janczewski 2000). The patients then has difficulty with pointing the direction of spinning. Such state is described as "dizziness". Such disorders can frequently be observed in case of elderly people, since the disorders are connected to the cognitive functions that decline with age (Pongrácz 2011, Maarsingh et al. 2010). The distinction between systemic and non-systemic dizziness is only the summary of medical history and the introduction to the further diagnosis (Table 1) (Prusiński 2011).

There is also a pathogenic and clinical classification of dizziness: labyrinthine and non-labyrinthine, paroxysmal and permanent, acute and chronic.

Table 1. Comparison of dizziness of central and peripheral origin

\begin{tabular}{|l|l|l|}
\hline Clinical signs & Dizziness of central (non-systemic) origin & Dizziness of peripheral (systemic) origin \\
\hline Character of complaints & $\begin{array}{l}\text { difficult to define sensation of staggering, } \\
\text { collapsing, } \\
\text { instable posture and walk }\end{array}$ & illusion of circular movement \\
\hline Beginning of symptoms & difficult to establish, gradual & sudden, paroxysmal \\
\hline Intensity & $\begin{array}{l}\text { moderate or low, symptoms of the same } \\
\text { intensity continue to be chronic }\end{array}$ & $\begin{array}{l}\text { the most intense symptoms at the beginning, } \\
\text { getting lower with time }\end{array}$ \\
\hline Single epizode & lasting few seconds, may cause a fall & $\begin{array}{l}\text { remaining for several minutes to several } \\
\text { hours }\end{array}$ \\
\hline
\end{tabular}




\begin{tabular}{|c|c|c|}
\hline Clinical signs & Dizziness of central (non-systemic) origin & Dizziness of peripheral (systemic) origin \\
\hline Duration of complaints & months, years & few weeks \\
\hline Head movement & small influence on the symptoms & intensifying the symptoms \\
\hline Hearing disorders & none & $\begin{array}{l}\text { there is often a hearing impairment, } \\
\text { usually on the damaged labyrinth's side }\end{array}$ \\
\hline Convulsion & possible & none \\
\hline $\begin{array}{l}\text { Disturbance } \\
\text { of consciousness }\end{array}$ & possible & none \\
\hline Headache & frequent & seldom \\
\hline Visual impairments & $\begin{array}{l}\text { diplopia, amblyopia, scotoma, } \\
\text { reduced visual acuity }\end{array}$ & none \\
\hline Symptoms of CNS damage & frequent limb and cranial nerves pareses & $\begin{array}{l}\text { there may only appear } \\
\text { a peripheral facial paresis }\end{array}$ \\
\hline Nystagmus & $\begin{array}{l}\text { spontaneous, high amplitude, } \\
\text { possible nystagmus of low amplitude }\end{array}$ & $\begin{array}{l}\text { horizontal, intensifying } \\
\text { with every direction of fixation }\end{array}$ \\
\hline
\end{tabular}

Source: Prusiński 2011; Szczeklik 2011; Litwin and Członkowska 2008.

\section{Terminology}

It is worth to add that concepts of "vertigo" and "dizziness" mean something different in the United States, whereas in other countries they can be used interchangeably. In Poland, each disorder of this type is called "dizziness" (Narożny et al. 2010).

In 1972, Drachman and Hart introduced the following concepts connected to balance disorder (no equivalent in Polish) (Tacikowska, Kubiczek-Jagielska 2010, Narożny et al. 2010):

- presyncope - it is caused by the reduced blood flow to the brain, resulted from the emotions or pressure drop. The patients pal. sweat, have narrow visual field, feel that their legs are weak ("feel groggy"), and their ears tingle.

- disequilibrium - occurs in case of patients with ataxia and loss of proprioception. The patients have a sensation of posture instability.

- lightheadedness - a difficult to define sensation of befuddlement, imbalance, described by the patients as "having a heavy head". The cause of symptoms is indefinable in case of those patients. It is suspected that this type of disorders is of functional origin.

\section{Causes of peripheral (systemic) dizziness}

\section{- Inflammation of vestibular neuron:}

Aetiology is not completely understood, although this affliction is usually preceded by viral infection. Therefore, there is an assumption that the virus is the main cause. It was impossible to dissect the contagium, therefore vascular aetiology and autoimmune aetiology are also taken into consideration. Mostly, it is a circular, sudden, and extreme dizziness which intensifies in time; it is often accompanied by vomiting and nausea (Kaski, Bronstein 2012). There are no hearing disorders, however, there is a horizontal nystagmus or horizontally rotational nystagmus. The attenuation or lack of excitability of labyrinth is shown by electronystagmography, and caloric stimulation is usually positive. In some cases, giving a small dose of steroids in the acute stage improves the long-standing prognosis. The anti-histamine and cholinolytic medicines are also applied and the vestibular rehabilitation is recommended as well (Zaper et al. 2012).

\section{- Benign paroxysmal positioning vertigo (BPPV):}

The aetilogy of this state is not completely explained, although it has been suspected that the essence of the disease is the inappropriate movement of otolithes in the semicircular canals as a result of traumatic and postinflamatory changes. The ailments are caused by a suden change of position, from seating to standing position or the rotational head movement. Tha attack is very short; it usually lasts less than 1 minute and it occurs during making the movement or in the so-called "critical position" (Balatsouras, Korres, 2012). It is often accompanied by a vertically rotational nystagmus. The hearing test is without any abberation. It is treated symptomatically and rehabilitatively using the freeing manoeuvres. The anti-histamine and cholinolytic medicines are used in the chronic therapy, but usually, taking them does not equal a complete remission (Continuum 2012). According to 
the Maslovara's research conducted on the patients with benign paroxysmal positioning vertigo, using the same pharmacotherapy of betanechol chloride for 8 weeks and introducing the rehabilitation for 8 weeks influenced the increase of negative caloric stimulation. Both types of treatment influences the improvement of this trial's results (Maslovara et al. 2012).

- Ménière's disease:

The aetiology is not completely understood. It has been assumed that the disease may be of autoimmune origin (Kozubski and Liberski, 2011). The symptoms are caused by an excess of endolymph in cochlea. Ménière's disease, also called the endolymphatic hydrops, appears as a result of increased pressure within the utricle (Janczewski 2000).There are three characteristic ailments: dizziness, tinnitus, hearing loss. After the attack, the hearing comes back to normal, although later there may occur a permanent damage of hearing. Nevertheless, it is rarely a severe hearing loss (Foster, Breeze 2013). The anti-histamine and cholinolytic medicines, giving medicines through the tympanum, and pressure therapy are applied in the attacks treatment. Limiting the sodium consumption is recommended prophylactically. The operational treatment is applied as the last resort. However, it affects the hearing disorder (Strupp, Brandt 2013). Ménière's disease concerns also the children. In Sweden, there were 4 cases of children aged 4-7 years old. Those patients were diagnosed with this disease, although it was impossible to get an objective description of hearing symptoms, which constitues the criteria for the diagnosis (Brantberg et al. 2002).

- Other causes of peripheral dizziness (Prusiński, 2002):

- injuries (damaging the semicircular canal. labyrinth concussion),

- labyrinth stroke,

- acute or chronic inflammation of middle ear,

- diseases of external ear,

- ototoxic medicines,

- congenital defect

- cancers.

\section{Causes of central (non-systemic) dizziness:}

\section{- Cerebral circulation disorders:}

The main disorders of blood supply within posterior cranial fossa (brain stem and cerebellum) as well as thalamus and cortex of temporoparietal area appear in dizziness. Circulatory insufficiency within the vascularity of vertebral artery and basilar artery causes not only the dizziness but also vomiting, nausea, visual impairment, dysarthria, dysphagia, and ataxia. Dizziness appears suddenly during the day or in the morning after getting up. The disorders of cerebral circulation appear frequently as the consequence of systemic disease, like hypertension, hyperlipidemia. Treatment is primarily concerned with the reduction of risk factors, normalization of pressure, rehabilitation, anticoagulants, anti-aggregation medicines (Prusiński 2002).

- Epilepsy:

Dizziness, connected to epilepsy, appears as paroxysmal disorders. They may precede a generalized epileptic seizure, be a part of partial seizure, or appear as an isolated seizure. It should be remembered that anti-epileptic medicines (e.g. carbamazepine) may cause the side effects, like dizziness (Prusiński, 2002).The electroencephalographic examination is very important, especially when dizziness appears as isolated seizure, i.e. vestibular epilepsy (Kozubski, Liberski 2011).

\section{- Migraine:}

Dizziness appears among the group of symptoms or it accompanies the pain in about $25 \%$ of patients suffering from migraine. The patients report the sensation of instability and collapsing. A slight dizziness appears as isolated symptom in case of migraine-related vestibulopathy (Neuhauser 2009).

- Other causes of central dizziness (Kulma 2009):

a. cerebellopontine angle tumors and compression changes of the posterior cranial fossa, hemangioma, metastatic tumor,

b. inner damage of brain stem (e.g. arteriovenous malformations),

c. damaging the eighth cranial nerve in systemic diseases,

d. paraneoplastic syndromes,

e. hereditary familial afflictions (e.g. spinocerebellar ataxia),

f. multiple sclerosis,

g. brain and cervical spine injuries,

h. atrophy of cerebellum. 


\section{Central-peripheral dizziness}

Ramsay Hunt syndrome type II, also known as herpes zoster oticus, and cancers are accompanied by the mixed, peripheral and central symptoms. At first, there is the peripheral dizziness. Then, other nerves are damaged and the central dizziness appears (Litwin, Członkowska 2008).

\section{Dizziness in systemic and functional disorders}

The dizziness may be caused by viral diseases (flu, measles, mumps), metabolic diseases, and hormonal diseases (diabetes, sclerosis, menopause) (Szczeklik 2011). Cardiac dysrhythmia should be highlighted among the factors that cause the cardiovascular dizziness (Tacikowska, Kubiczek-Jagielska 2010).

The described disorders appear also in case of neurosis and depression. However, they recede as the mental state is healed. This is the so-called functional dizziness.

\section{Diagnostics}

Collecting a precise medical history of the patient suffering from dizziness is crucial because the further diagnostic process depends on it. The patients should describe the beginning of ailments, whether they appeared suddenly or were gradually intensifying, the duration of attack, the frequency of recurrences, the causing factors (verticalization, change of head position, small amount of sleep, infections, hypertension, taking medicines). The patient, who describes dizziness as the sensation of staggering and collapsing, complaining about the posture and walk instability, should be referred to tests that confirm the central dizziness. However, if the patient has the illusion of circular movement, it indicates the peripheral nature of dizziness. Nevertheless, it is not the rule and the patient's sensations are subjective. Other symptoms accompanying the dizziness are also important, e.g. hearing loss, earaches, ailments connected to damaging other cranial nerves, disturbances of consciousness, symptoms of focal brain injury (Tacikowska, Kubiczek-Jagielska 2010).

The physical examination should include static-dynamic tests, i.e. the Romberg's test, the Babiński-Weil's test, and the Unterberger's test. The occurrence of nystagmus, its direction, amplitude, and duration can be examined by electronystagmography, videonystagmography, and caloric stimulation (Hallpike's test). It is important to examine the eye movement as the disorder may indicate the central damage. It is necessary to do the otoscopic examination, pure tone audiometry, and impedance audiometry, brainstem auditory potentials.

If the cause is still unknown, there is a need for neuroimaging examination (computer tomography/magnetic resonance), posturography, examination of blood flow in extracranial and intracranial arteries, and serological examinations (Litwin, Członkowska 2008).

\section{Therapeutic procedures}

The condition and functioning of a patient with dizziness should be assessed in the hospital emergency ward after collecting the medical history and doing the physical examination of the patient. It should be decided whether the patients is able to keep the static and dynamic posture and whether there is a risk of fall (Tacikowska, KubiczekJagielska 2010). The neurologist and otolaryngologist should decide on the further diagnostic process and put the treatment into practice after finding the cause.

The treatment of dizziness connected to the systemic diseases, migraine, epilepsy, or multiple sclerosis is based on the casual treatment and supportive symptomatic treatment. Antivertiginosa is a term defining the medicines which reduce the sensation of dizziness and accompanying symptoms, e.g. anxiety. Such medicines include the following groups: medicines inhibiting the CNS (neuroleptics, anxiolytics, first-generation antihistamines, cholinolytics), vascular medicines (calcium antagonists, nicotin acid and its methylxanthene derivative, medicines blocking the a-adrenergic receptors), cytoprotective medicines (neuroprotective) (Litwin, Członkowska 2008).

Operational treatment concerns the cases when the cause of dizziness is known (e.g. otosclerosis, fistula, proliferative changes, some of the vascular disorders), when the improvement after the conservative treatment is insufficient and the vestibular symptoms are progressive (Tacikowska, Kubiczek-Jagielska 2010).

The vestibular rehabilitation is a very important element of therapy in case of many patients and it should be taken into consideration while planning the dizziness treatment according to the latest standards (Obrębowicz 2010). Currently, it includes: the movement therapy stimulating the processes of vestibular disorders compensation and the therapy of benign paroxysmal positioning vertigo (Józefowicz-Korczyńska 2010). The rehabilitation is based on two mechanisms that exist mainly in cerebellum and brain stem: adaptation and compensation (Shepard, Telian 1995).

The procedure concerning the particular disease entities has been described above, while discussing the causes of peripheral and central dizziness. 


\section{Conclusions}

It is extremely difficult to compare the examinations done in different parts of the world due to the unsystematic terminology concerning dizziness and unsystematic methodology of examining dizziness and balance disorders. The lack of normalized concepts may easily cause the confusion and it would be harder for a doctor to use the provided information.

As the article emphasizes, the neurologist and otolaryngologist are not the only ones who should demonstrate their knowledge concerning dizziness, since dizziness is a problem that patients report to doctors of various specialities. It is necessary to remember that the cause of dizziness always has to be found, although dizziness is usually mild and unrelated to excess mortality.

\section{References:}

1. Balatsouras D.G., Korres S.G. (2012), Subjective benignparoxysmal positional vertigo. Otolaryngol Head Neck Surg. Jan; 146(1): 98-103.

2. Brantberg K., Duan M., Falahat B. (2012), Ménière's disease in children aged 4-7 years. Acta Otolaryngol. May; 132(5): 505-9.

3. Colledge N.R. (1999), The prevelence and characteristics of dizziness in the elderly community. Age Ageing; 48: 1131-1135.

4. Continuum M.M. (2012), Positional dizziness. Neurootology Oct; 18(5): 1060-85.

5. Dietrich M. (2002). Vaskulaerer Schwindel. Nervenarzt 73: 1133-1143.

6. Domżał T.M. (2010), Zawroty układowe czy nieukładowe? Vertigoprofil;4: 7-13.

7. Foster C.A., Breeze R.E. (2013), Endolymphatic Hydrops in Ménière's Disease: Cause, Consequence, or Epiphenomenon? Otol Neurotol. Sep; 34(7): 1210-4.

8. Janczewski G. (2000), Zawroty głowy. Solvay Pharma, Warszawa.

9. Józefowicz-Korczyńska M. (2010), Rehabilitacja zawrotów głowy i zaburzeń równowagi. Otolaryngologia; 9(1): 7-12

10. Kaski D., Bronstein A.M. (2012), BMJ. Making a diagnosis in patients who present with vertigo. BMJ Sep 3:345.

11. Kozubski W., Liberski P. (2011), Neurologia. PZWL. Warszawa

12. Kroenke K., Hoffman R.M., Einstadter D. (2000), How common are various causes of dizziness? A critical review. South Med. J.; 93 (2): 160-167.

13. Kulma D. (2009), Vertigo as the medical certification issue. Orzecznictwo Lekarskie 6 (2): 135-147].

14. Litwin T., Członkowska A. (2008), Zawroty głowy w praktyce neurologa - diagnostyka i leczenie. Polski Przegląd Neurologiczny; 4(2): 78-86.

15. Lo A.X. (2013), Geriatric dizziness: evolving diagnostic and therapeutic approaches for the emergency department. Clin Geriatr Med. Feb; 29(1): 181-204.

16. Maarsingh O.R., Dros J., Schellevis F.G. (2010), Causes of persistent dizziness in elderly patients in primary care. Ann. Fam. Med.; 8: 196-205.

17. Maslovara S., Soldo S.B., Puksec M. (2012), Benignparoxysmal positional vertigo (BPPV): influence of pharmacotherapy and rehabilitation therapy on patients' recovery rate and life quality. NeuroRehabilitation, 31(4): 435-41.

18. Narożny W., Siebert J., Wojtczak R. (2010), Epidemiologia zawrotów głowy i zaburzeń równowagi. Forum Medycyny Rodzinnej. 4 (5): 356-365).

19. Neuhauser H. (2009), Epidemiology of vertigo, migraine and vestibular migraine. J. Neur.; 256: 333-338.

20. Neuhauser H.K, Lempert T. (2009), Vertigo: epidemiologic aspects. Semin Neurol. Nov; 29(5): 473-81.

21. Niemensivu R., Pyykkö I., Wiener-Vacher S.R. (2006), Vertigo and balance problems in children- an epidemiologic study in Finland. Int.J. Ped. Otorhinolaryngol.; 70: 259-265.

22. Obrębowicz A. (2010), Standardy rozpoznawania i leczenia zawrotów głowy. Oinpharma, Warszawa.

23. Pongrácz E. (2011), Interdisciplinary approach to vestibular system impairment. Ideggyogy Sz 30; 64(3-4): 101-9.

24. Prusiński A. (2011), Klasyfikacja, obraz kliniczny i leczenie zawrotów głowy. Polski Przegląd Neurologiczny, t 7: 1.

25. Prusiński A. (2002), Zawroty głowy. PZWL, Warszawa.

26. Saber Tehrani A.S., Coughlan D., Hsieh Y.H. (2013), Rising annual costs of dizziness presentations to U.S. Emergency departments. Acad Emerg Med. Jul; 20 (7): 689-96.

27. Seemungal B.M. (2007), Neuro-otological emergencies. Curr. Opin. Neurol.; 20: 32-39. 
28. Shepard N., Telian S. (1995), Programmatic vestibular rehabilitation. Otolaryngol Head Neck Surg; 133: $323-5$.

29. Storper I.S. (2005), Dizzines and hearing loss. W: Rowland L.P. (red.). Merrit's Neurology, 11th ed. Lippincott Williams \& Wilkins, Philadelphia.

30. Strupp M., Brandt T. (2013), Peripheral vestibular disorders. Curr Opin Neurol. Feb; 26(1): 81-9.

31. Szczeklik A. (2011), Choroby wewnętrzne. Medycyna Praktyczna, Kraków.

32. Tacikowska G., Kubiczek-Jagielska M. (2002), Schemat postępowania terapeutycznego w zawrotach głowy. Instytut Fizjologii i Patologii, Warszawa.

33. Zaper D., Adamec I., Gabelić T. (2012), Vestibular neuronitis: pathophysiology, diagnosis and treatment. Lijec Vjesn. Nov-Dec; 134(11-12): 340-5.

Submitted: 31.07 .2014

Accepted: 24.10 .2014 